\title{
The Impact of Physical Activity on Mental Health and Psychological Well-Being, Perspectives on Improving the Educational Curriculum
}

Theodoratou $\mathbf{M}^{1}$, Kalafatis $D^{2}$ and Panitsa $G^{3}$

${ }^{1}$ Hellenic Open University, Greece

${ }^{2}$ Generation 2.0 for Rights, Equality and Diversity, Greece

${ }^{3}$ Cambridge Assessment, University of Cambridge, UK

\author{
"Correspondence author \\ Theodoratou M \\ Hellenic Open University, \\ Greece
}

Submitted : 9 April 2020 ; Published : 9 May 2020

\begin{abstract}
The aim of this study is to give a meaningful analysis of physical activity consolidating to its advantages on mental health and prosperity undertakings. Aspects of mental prosperity analyzed in the context of general prosperity with specific reference to self-recognition have enabled us to highlight the connection between physical activity, mental prosperity, well-being and self-discernment. We have also looked at the alternation between physical activity and selfobservation: we outline their strong association. Finally, segment factors, namely age, sex and socio-economic status, are contemplated to reveal how they impact on prosperity when these are looked at together with physical exercise. We analyse the effect these factors may have on one's self discernment as well as the utilization of physical exercise as an applied intercession to forestall negative mental prosperity. Last but not least, given the importance of good mental health for young people too, we stress its importance for them and how it can be maintained through physical activity; for mental health should be addressed in the educational curriculum, should be monitored by specialists in our educational communities and should be taken into consideration when students sit important summative assessments.
\end{abstract}

Keywords: Physical Activity, Self-Perception, Psychological Well-being, Mental Health, Youth, Educational curriculum, Summative assessment

\section{Abstract}

A direct relation between physical and mental health was already observed in ancient times. This is evident from the principle of Hippocrates saying: "Healthy body in a healthy mind" [1].

Lasker, Weiss, and Miller mentioned that a one-of-a-kind favorable position of coordinated effort could be acknowledged when the organization is overall more noteworthy than its parts. For instance, training and exercise, nutrition and brain science are progressively converging to comprehend health in an all-encompassing manner. For approximately 20 years, the investigation of well-being has been merging several approaches to portray a broader methodology that would help understand self-improvement and personal satisfaction better $[2]$.

The motivation behind this exploration is to gain thorough knowledge of the impact of physical activity (PA) and the effects it has on psychological well-being (PWB). |For instance, how being physically active impacts mental well-being or the effects of being physically inactive and what would be the results of such behavior. A passive way of living has turned into a medical problem of extraordinary worry throughout recent years [3].

Nowadays there are unquestionably more open doors for stationary options in contrast to active ways of life in comparison to any time in recent memory [4]. Research has even shown that passive life is related to more unfortunate emotional well-being scores [5]. During the last three decades physical activity has ascended to a notable extent as both an open issue and as a research intrigue. It tends to be ascribed to conceivably three factors. The first refers to the inactive way of living mentioned previously. The second denotes the results of 
physical dormancy, with the third being the knowledge picked up in the positive outcomes of physical movement on wellbeing and the advantages it may provide [6].

The prevalence of dysfunctional behaviors such as despondency, nervousness, character issues combined with the consistently expanding issue of heftiness and other dietary problems that the world appears to look at as bleak spot as it's been demonstrated that with normal physical movement these issues are decreased [7-9]. It is expected that by 2020 disease will be the subsequent driving reason for the ailment around the world [10].

The modern scientific logic of PA research started in the mid1950s in London [11]. Morris et al, examined the death paces of London Transport Executive and Post-Office representatives and watched lower death rates from coronary issues in physically dynamic workers (transport conductors and postmen) than in their stationary partners (bus-drivers, phone switchboard operators). From that point forward, explore the potential medical advantages of PA has been prospering. Early life PA has appeared to advance the arrangement of thick, well-mineralized bones, just as impact the bone basic geometry $[12,13]$. In addition, a backward affiliation exists among PA and all-cause mortality, cardiovascular occasions, for example, myocardial localized necrosis, hypertension, obesity, and type II diabetes [14-21]. Besides, PA has been related with advantages to the insusceptible system and cerebrum work; since it builds the blood and oxygen stream in the mind [22-24]. Lastly, PA has been emphatically connected with neurogenesis, gliogenesis and neuroprotection in certain territories of the creature and human cerebrum, just as with subjective enhancements in little youngsters, teenagers, and more seasoned grown-ups [25-31]. The estimated system for these advantages is the enactment of neurotrophins, what's more, other development factors, for example, Brain-Derived Neurotrophic Factor (BDNF).

\section{Defining Physical Exercise}

Taking part in PA is probably the most ideal approach to improve physical and mental well-being just as emotional wellbeing. "Physical Activity," "exercise," and "physical fitness" are terms that describe different concepts [32]. Physical action is characterized as any substantial development delivered by skeletal muscles that outcomes in vitality use [3].

Physical movement in day by day life can be arranged into word related, sports, conditioning, family unit, or different exercises. Exercise is a subset of physical activity that is arranged, organized, and dull and has as a last or a moderate target the improvement or upkeep of physical wellness. Physical fitness is a lot of traits that are either well-being or ability related [33].

General Health and Social advantages of Physical Exercise

Critical medical advantages can be accomplished from customary PA, the appropriate measure of PA which is at any rate 30 minutes of moderate action multi-day, 5 times each week, or 20 minutes of lively action at any rate 3 days every week as per Gorin and Arnold, produce positive results on mental and general well-being.

A developing collection of proof perceived that customary exercise has numerous helpful impacts on well-being and life fulfillment [34]. The advantages influence mental, physical well-being and life fulfillment. Physical Activity (PA) keeps up a solid body and there is a mounting group of research to recommend that taking part in customary PA brings down the danger of cardiovascular ailments, malignant growth, and diabetes and shows benefits for superior personal satisfaction. Performing physical movement all the time will improve by and large well-being and wellness, just as diminishing the hazard for some, incessant maladies [35].

Research affirms that PA is valuable in lessening levels of wrongdoing and hostile to social conduct, it increments sound practices and allows a person to mingle and meet new individuals [36]. The wealth of research on physical movement led in the course of recent years, mostly because of the seismic impact of the U.S. distributed 'A report of the Surgeon General' in 1996, shows that PA decreases the danger of coronary illness, it impacts different restorative issue and PA improves mental prosperity and furthermore adds to positive emotional wellness all through life [3, 36-38].

The acknowledgment that PA has boundless advantages on (physical) well-being has prompted the investigation of whether the advantages of PA can likewise stretch out to prosperity and emotional wellness. The primary epidemiological investigations indicated empowering results [8]. Netz et al, in an enormous investigation of more than 55.000 people, presumed that there was a reasonably constructive relationship between PA and prosperity, constructive temperament and lower levels of nervousness and wretchedness. A few later investigations have additionally demonstrated a positive connection between PA and psychological wellness [39, 40].

\section{Mental well-being}

Mental well-being (PWB) is a multidimensional idea that alludes to having a positive perspective on one's self and one's life and incorporates parts of confidence and fulfillment with life, notwithstanding one having a generally negative low feeling, and positive high feeling [41]. PWB consists of a more eudemonistic point of view with a bit of a decadent point of view included. Associates of PWB are age, relationship status, business status pay, and physical well-being to give some examples. It is a key part of the life of an individual, it brings (if positive) joy, positive confidence, positive emotional wellness, ideal intellectual execution and propels the person to accomplish objectives all through life. Despite what might be expected if a person's PWB is pessimistic, particularly for a delayed time frame, they can build up a range psychological maladjustment or scatters, for example, nervousness or gloom, which can further form into physiological issues and cause 
upset for the individual both inside and remotely [42, 43].

PWB conceptualizations have been different as it is especially an abstract variable; also, it is an idea containing both enthusiastic and subjective components. PWB is thought to incorporate 6 key measurements; they are selfacknowledgment, positive relations with others, self-rule, natural dominance, reason throughout everyday life, and selfawareness [44]. Others might be temperament, prosperity, personal satisfaction, general well-being, a reason throughout everyday life, capability and imperativeness, in this way it is hard to create a particular definition since these measurements differ every once in a while, and are hard to quantify $[45,46]$. Be that as it may, the different parts of mental prosperity watch out for co-happen and their measures are profoundly connected with one another, shaping a solid higher request factor for that subject [47].

\section{Research on Psychological Wellness}

Albeit a wide term and falling under a general class of brain science, investigate PWB is boundless and it has been broadly investigated in the course of recent years [48]. What was found during the two decades was that negative PWB has a noteworthy impact on psychological sicknesses, for instance, negative PWB corresponds with discouragement, it negatively affects nervousness and moreover on stress [49-51]. Different discoveries were that PWB is composed of various measurements and keeps running along a continuum from working at one's fullest ability to add up to mental trouble.

Current writing affirms that various parts of positive mental prosperity influence a person's well-being in a fundamental manner. For instance, good faith is related with decreased cardiovascular mortality and lessens episode danger of coronary heart disease (CHD), as referred to in Boehm, Peterson, Kivimaki, and Kubzansky, others, for instance, Baruth et al, found that good faith has a positive huge association with expanded physical movement. Different investigations express that larger amounts of PWB were connected reliably to a diminished danger of CHD [35, 52-54]. Positive PWB has likewise appeared to impact the cardiovascular reaction to push. Fredrickson, Mancuso, Branigan, also, Tugade presented volunteers to an upsetting undertaking which was trailed by a state of mind acceptance system [55]. Members feeling positive state demonstrated an increasingly fast cardiovascular recuperation from worry than those in a negative or impartial temperament state.

\section{On Self-Perception}

As indicated by Azizi and Jaafar, everyone has an image or view of themselves [56]. Self-perception (SP) is characterized as a procedure of personality development through tactile discernment, and it enables us to comprehend our own behavior, conduct, feelings, and sentiments. SP is a multifactorial idea including psychological, perceptual, and full of feeling, evaluative and social segments [57]. Bean
Lipka and Shavelson express that self-recognition comprises various parts of oneself; they suggest that confidence and selfidea make up self-observation (both are hierarchical ideas in one) [58].

Individuals with a positive self-recognition feel cheerful about the way they look and are delightful in their very own skin, they're persuaded and persevering, they can acknowledge analysis in a positive manner, be objective and have a certain point of view $[59,60]$. Though individuals with a negative self -observation are restless about the way they look, they feel awkward in specific circumstances, it is identified with misery and can even reason an individual to be self-destructive [61, $62]$.

The issue with self discernment today isn't so much positive SP however negative SP. Negative SP is turning into an expanding issue, it influences a person's insights, a need for certainty emerges and contrary SP impacts individuals' observations about themselves. Negative SP creates insight into a person's own self idea, for instance, media pictures, TV and magazines are found to influence ladies' self recognitions contrarily [63, 64]. Strong physical make-up and media pictures may likewise impact a person's self-observation adversely. Other negative self-recognition can be a person's poor self -judgment, cynicism and an absence of will to appreciate life.

It is not simply media and TV that impact a person's impression of themselves, character types influence it as well. Sticklers, high achievers, and those with "type A" characters appear to be inclined to having negative mental self-portraits [65]. Selfobservation can likewise influence mortality as Levy, Slade, Kunkel, and Kasl found [66]. Their exploration expressed more established people that had an increasingly constructive self-view of maturing, estimated as long as 23 years sooner, lived 7.5 years longer than those with more negative selfperceptions of maturing.

SP is a tremendous conceptual build, it impacts numerous ideas in a subject, about how other individuals see them and how they see themselves, which includes numerous subjective procedures, what's more, SP is particularly an emotional variable. The wide range of measurements of SP demonstrate that it is hard to quantify; anyway, it is by all accounts a subset of mental prosperity, so ideally through this examination venture a connection will be made between the two [67]. The Body Esteem Scale (BES) was utilized to quantify selfdiscernment in this investigation as self-perception is one's interior impression of, frame of mind towards, and distraction with one's body size and shape, and since self-recognition can be alluded to by numerous ideas, this present investigation alludes it to a person's self-saw self-perception and how they feel about their body both from the inside and remotely [68, 69]. The body is experienced as a declaration of oneself states Fallon as referred to in Cash and Pruzinsky and of one's self discernment [70]. 
Correlating Physical Activity with Psychological Wellness and Self-Perception

Probably the most well-known advantages yielded from physical activity are that it helps control weight, it keeps up bones and muscles in an individual, yet, above all, it advances mental prosperity. As per investigate on this point it is getting to be progressively obvious that normal physical movement affects mental prosperity, for example, it impacts the treatment of mental issues decidedly. Results from a meta-examination directed by Lawlor and Hopker explored the impacts of physical movement as a treatment for gloom and reasoned that physical movement prompted a more prominent decrease in burdensome indications contrasted with no treatment by any stretch of the imagination. It likewise has a much more prominent impact on those with an inclined mental issue [71].

\section{Physical Activity and Psychological Wellness}

PA associates with great psychological well-being and being less inclined to manifestations of uneasiness and sadness [72]. Biddle and Mutrie expressed that solid types of activity can assume a key job in the advancement of psychological wellness and prosperity [73]. That even impacts cognizance, psychological debilitation is half less inclined to happen in physically dynamic individuals, revealed Stewart, Richards, Brayne and Mann [74]. On the off chance that normal physical movement is taken an interest in, at that point a person's mental prosperity improves [75-78]. Different advantages that PWB gets because of PA are improved mindset states [79].

So, if customary PA is expanded extraordinarily the advancement of a person's well-being and psychological prosperity improves considerably more than typical. This is not the situation. There is developing proof gone for the risk of overtraining or surpassing your points of confinement during any physical movement. This can prompt long haul harm, for example, muscle joint and pain, persistent weariness, aggravations in PWB and state of mind, expanded rate of wounds and inordinate weight reduction [80]. An investigation on the effect of PA on health-related quality of life (HRQL) or saw well-being status found that people that take part in the suggested to PA sum would do well to generally speaking view of well-being and HRQL, in this way forcing a moderate instead of serious physical action may be additionally fulfilling $[81,82]$.

Another reason with respect to why PA prompts superior mental prosperity lies in the neurological premise. An endorphin surges accomplished from being physically dynamic, with this, an individual gets a mental 'high' from the arrival of endorphins because of activity or PA. The catecholamine theory might be another neurological clarification; this recommends exercise and PA discharge catecholamine (dopamine, nor adrenaline, and adrenaline) which in turn are related to positive disposition states and rapture. Also, a third reason lies in the authority theory, this speculation expresses that any activity which requires explicit abilities is probably going to positively affect self-effectiveness, this makes uplifted confidence and made a positive influence state [83, 84].

\section{On Physical Activity and Self Perception}

Research looking at the impacts of sports and physical activity has connected them to improved self-perception [85]. Gettogether comprising physical movement or exercise can prompt expanded positive self idea in grown-ups, similarly, people inside a physical action gathering have higher selfperception fulfillment than stationary people $[86,87]$. There is clear proof that activity and PA can change individuals' views of their physical selves in a constructive way, even in doing any activity all the time can make individuals rest easy thinking about themselves discernment [88]. Aggravations in self-perception may prompt dietary issues or psychological instabilities, for example, misery just as low confidence [89]. That influences immaturity mental self-portrait emphatically states Kirkcaldy, Shephard, and Siefen, and as indicated by Serdula, Williamson, Anda, Heaton, and Byers practice has been utilized by about $90 \%$ of people as a method for attempting to alter or control body size and shape [90, 91]. People who are physically dynamic keep up preferred degrees of self-recognition over the individuals who are stationary [92]. This additionally works the other way recommends Harter's ability inspiration hypothesis; he expressed that one's physical self-discernment might be an intention in starting and keeping up PA intercessions or projects [93].

However, self-discernment is difficult to gauge as it is socially one-sided, for example in Europe the flimsy perfect is the alleged 'immaculate' figure for females while the strong physical make-up is for guys, and self-perception is particularly overemphasized upon and esteemed excessively. Interestingly in Africa weight raises to riches, so the man with a touch of weight is viewed as rich, upbeat and substance with life, this is the perfect discernment for one's self-perception in the African populace in light of these positive angles being what the Western culture would call overweight. Indeed, even African ladies expressed their accomplices didn't need to shed pounds to be alluring, along these lines showing that it is acknowledged [94]. SP is additionally impacted by numerous builds of oneself and the advancement of self-discernment isn't yet completely comprehended. This makes it hard to make an all-inclusive instrument to gauge self discernment. However, the body esteem scale (BES) is utilized in this examination and has subscales for the two male and two female with pertinent legitimacy in an overall example, so before the part of the bargain venture, the outcomes ought to be reliable because of the estimation utilized.

Physical Activity as an applied intercession for negative Psychological Well-being

Intercessions to build PWB are quickly being created, both for the prevention and treatment of depression, treatment of sorrow and another mental issue $[95,96]$. These intercessions incorporate physical action meditations, for instance, 
psychomotor treatment or even any kind of physical movement performed reliably for the suggested time by a specialist. Some meta-systematic discoveries demonstrate a huge impact size from examines that have utilized exercise as an intercession for the treatment of despondency [73]. Dad as high-impact workout, even in short sessions, additionally decreases nervousness states [97, 98]. Wang et al. associated judo (a type of low sway mind-body work out) with upgrades in mental prosperity including diminished stress, discouragement, uneasiness, and state of mind unsettling influences [99]. Leith in explored twenty exploratory investigations on the impacts of the activity on PWB, finding in fourteen of them (70\%) that activity is viable in decreasing tension; these discoveries are steady with Ekkekaki's article on points of view from exercise [100].

As an outcome of these results, PA has been progressively used to treat mental trouble or negative PWB today, and the impacts are essentially superior to treating them with drugs [101]. PA is additionally practical contrasted with other mental prosperity medicines, and Biddle, Fox, and Boutcher express a few reasons why physical movement ought to be utilized as mediation for negative PWB. Their book looks at the numerous impacts PA has on PWB, for instance, members in clinical settings can profit by great momentary episodes of activity, physical movement is continually connected with a state of mind and influence, and trial research bolsters that moderate exercise on PWB.

Segment Variables Correlated with Physical Exercise, Psychological Well-being and Self Perception

Age, sex, employment and financial status all have a hidden impact and add to how physical action advances mental prosperity, how powerful it will be and how open it is for people. For example, as a subject ages, physical movement diminishes [102]. The HBSC Ireland short report on physical activity detailed the recurrence of moderate to energetic PA being higher in youthful understudies than in older age gatherings. This is seen much through research, which as an individual age their PA diminishes.

Comparative reviews have been conducted that look at the connection between physical exercise and psychological wellness considering age as a key factor. One of them focused on researching whether physical action impacts youth' and youngsters' feelings, confidence and as a result emotional well-being. Material Questionnaires were redacted by the exploration group examining members' propensities, feelings and medical advantages concerning physical exercises. Technique Questionnaires were controlled to 150 youths, matured 18-20 years of age in Technological Educational Institutes, universities and wellness focus in Patras, Southern Greece throughout 2015's spring. Results Eighty-seven percent of the respondents turned out in wellness focuses or in regular habitat. The majority of them addressed that activity added to renewal and elation sentiments (63\%), stress help (78\%), better mental self-portrait, and better well-being (49\%). As indicated by $63 \%$ of the young people, practice improved their school execution and $61 \%$ of them felt that activity influenced emphatically psychological wellbeing. Ends Present investigation's outcomes underline physical exercises' advantages in understudies' psychological wellness, confidence, sentiments and school execution being in accordance with other examinations' outcomes [103, 104]. Limitations allude for the most part to little estimate test [105].

Further research has expressed that sexual orientation is a powerful factor as it's demonstrated that standard physical action is taken part more in guys than females along these lines affecting their mental well-being [106]. Comparable discoveries have been the reliably connected ender with selfrecognition; a significant part of the writing on self-observation and sexual orientation contrasts has led to guys having a higher by and large self-view of themselves than females do [107$110]$.

\section{Physical exercise, mental health and the youth}

Undeniably the impact of physical exercise on mental health and psychological well-being is tremendous. Nowadays the issue of the mental health of young people is on the forefront; it is therefore imperative that young people, school kids and teenagers, are well informed about the importance of undertaking any form of physical activity, as this is key to their psychological well-being. Ideally, maintaining good mental health and the need to exercise to do so, should be addressed at school; this would need to be a school subject, an important one. At the same time, school authorities should be able to monitor the young people's mental health and support young people by providing suitable physical exercise programmes and by supporting them along their education path and especially when students of different ages sit important summative assessments. The impact of physical exercise on mental health during such highly stressful periods in student life cannot be stressed enough and should be addressed in schools and educational institutions. This will remain the subject of further research.

\section{References}

1. Lasker RD, Weiss E, Miller R (2001) Partnership synergy: A practical framework for studying and strengthening the collaborative advantage. Milbank Quarterly 79: 179-205.

2. Myers J, Sweeney T, Witmer J (2000) The wheel of wellness counseling for wellness: A holistic model for treatment planning. Journal of Counseling \& Development 78: 251-266.

3. World Health Organization (2004) Global Strategy on Diet, Physical Activity and Health. Geneva: World Health Organisation.

4. Norman GJ, Schmid BA, Sallis JF, Calfas KJ, Patrick K (2005) Psychosocial and environmental correlates of adolescent sedentary behaviours. Pediatrics 116: 908-916.

5. Hamer M, Stamatakis E, Mishra G (2010) Television- and screen-based activity and mental well-being in adults. 
American Journal of Preventive Medicine 38: 375-380.

6. Haskell WL, Lee IM, Pate RR, Powell KE, Blair SN, et al. (2007) Physical activity and public health: Updated recommendation for 317 adults from the American College of Sports Medicine and the American Heart Association. Medicine \& Science in Sports \& Exercise 39: 1423-1434.

7. Myers J (2003) Exercise and Cardiovascular Health. Circulation 107: 2-5.

8. Netz Y, Wu MJ, Becker BJ, Tenenbaum G (2005) Physical activity and psychological well-being in an advanced age: A meta-analysis of intervention studies. Psychology and Ageing 20: 272-284.

9. Herring MP, O’Connor PJ, Dishman R (2010) The effect of exercise training on anxiety symptoms among patients. Archives of Internal Medicine 170: 321-331.

10. Morgan K, O'Farrell J, Doyle F, McGee H (2011) Physical activity and core depressive symptoms in the older Irish adult population. A project funded by the Centre for Ageing Research and Development in Ireland (CARDI). Dublin: Royal College of Surgeons in Ireland.

11. Morris JN, Crawforf MD (1958) Coronary heart disease and physical activity of work; evidence of a national necropsy survey. British medical journal 2: 1485-1496.

12. Burr DB, Ruff CB, Thompson DD (1990) Paterns of Skeletal Histologic Change through Time: Comparison of an Archaic Native American Population with Modern Populations. Anat Rec 1990: 226-301.

13. Larsen C (1997) Bioarchaeology: Interpreting Behavior from the Human Skeleton. Cambridge: Cambridge University Press.

14. Paffenbarger Jr RS, Hyde RT, Wing AL, Hsieh CC (1986) Physical activity, all-cause mortality, and longevity of college alumni. The New England Journal of Medicine 314: 605-613.

15. Powell KE, Blair SN (1994) The public health burdens of sedentary living habits: theoretical but realistic estimates. Medicine and science in sports and exercise 26: 851-856.

16. Kottke TE, AulikkiNissinen A, Puska P, Salonen JT, Tuomilehto J (1984) Message Dissemination for a Community-based Cardiovascular Disease Prevention Programme (The North Karelia Project), Scandinavian Journal of Primary Health Care 2: 99-104.

17. Balady GJ (2002) Survival of the fittest-more evidence. $\mathrm{N}$ Engl J Med 346: 852-854.

18. Myers J, Prakash M, Froelicher V, Partington S, Atwood J (2002) Exercise Capacity and Mortality among Men Referred for Exercise Testing. The New England journal of medicine 346: 793-801.

19. Fagard R (2001) Exercise characteristics and the blood pressure response to dynamic physical training. Medicine and science in sports and exercise 33: S484-S493.

20. Prentice AM, Jebb SA (2000) Physical activity level and weight control in adults. In C. Bouchard (Ed.) Physical activity and obesity 2000: 247-261.

21. Hardman AE, Stensel DJ (2003) Physical activity and health: The evidence explained. London: Routledge.

22. Pedersen BK, Hoffman-Goetz L (2000) Exercise and the immune system: regulation, integration, and adaptation.
Physiological reviews 80: 1055-1081.

23. Bouchard C, Shephard RJ (1994) Physical Activity, Fitness and Health: The Model and Key Concepts. In: Bouchard, C., Shephard, R.J. and Stephens, T., Eds., Physical Activity, Fitness and Health: International Proceeding and Consensus Statement. Human Kinetics, Ed. Champaign, Illinois.

24. Dishman R, Hales D, Pfeiffer K, Felton G, Saunders $\mathrm{R}$, et al. (2006) Physical self-concept and self-esteem mediate cross-sectional relations of physical activity and sport participation with depression symptoms among adolescent girls. Health psychology: official journal of the Division of Health Psychology. American Psychological Association 25: 396-407.

25. Van Praag H, Kempermann G, Gage FH (1999) Running increases cell proliferation and neurogenesis in the adult mouse dentate gyrus. Nature Neuroscience 2: 266-270.

26. Van Praag H, Christie B, Sejnowski T, Gage F (1999) Running Enhances Neurogenesis, Learning, and LongTerm Potentiation in Mice. Proceedings of the National Academy of Sciences of the United States of America 96: 13427-13431.

27. Van Praag H (2008) Neurogenesis and Exercise: Past and Future Directions. Neuromolecular medicine 10: 128-140.

28. Chaddock L, Hillman C, Buck S, Cohen N (2011) Aerobic Fitness and Executive Control of Relational Memory in Preadolescent Children. Medicine and science in sports and exercise 43: 344-349.

29. Hillman CH, Erickson KI, Kramer AF (2008) Be smart, exercise your heart: Exercise effects on brain and cognition. Nature Reviews Neuroscience 9: 58-65.

30. Colcombe S, Kramer AF (2003) Fitness effects on the cognitive function of older adults: A meta-analytic study. Psychological Science 14: 125-130.

31. Colcombe SJ, Arthur F Kramer, Kirk I Erickson, Paige Scalf, Edward McAuley, et al. (2004) Cardiovascular Fitness, Cortical Plasticity, and Aging. Proceedings of the National Academy of Sciences of the United States of America 101: 3316-3321.

32. Caspersen CJ, Powell KE, Christenson GM (1985) Physical activity, exercise, and physical fitness: Definitions and distinctions for health-related research. Public Health Reports 100: 126-131.

33. Caspersen CJ, Pereira MA, Curran KM (2000) Changes in Physical Activity Patterns in the United States, by Sex and Cross-Sectional Age. Medicine and Science in Sports and Exercise 32: 1601-1609.

34. Diener E, Chan M (2011) Happy People Live Longer: Subjective Well-Being Contributes to Health and Longevity. Applied Psychology: Health and Well-Being 3: 1-43.

35. Boehm JK, Peterson C, Kivimaki M, Kubzansky L (2011) A Prospective Study of Positive Psychological Well-Being and Coronary Heart Disease. Health Psychology 30: 259267.

36. Cavill N, Kahlmeier S, Racioppi F (2006) Physical activity and Health in Europe: evidence in action. Genoa: World Health Organization. 
37. World Health Organisation (2002) The World Health Report. Reducing risks, prompting Healthy life. Geneva: World Health Organisation.

38. Von Bonsdorff MB, Ranten T, Leinonen R, Kujala UM, Tormakangas T, et al. (2009) Physical activity improves life expectancy and end-of-life hospital and long-term care. The Journals of Gerontology. Series A, Biological Sciences and Medical Sciences 7: 778-784.

39. Deslandes Andréa, Moraes Helena, FerreiraVorkapic, Camila Alves, Heloisa Silveira, et al. (2009) Exercise and Mental Health: Many Reasons to Move. Neuropsychobiology 59: 191-198.

40. Paluska SA, Schwenk T (2000) Physical activity and mental health: Current concepts. Sports medicine (Auckland, N.Z.) 29: 167-180.

41. Lent RW (2004) Toward a unifying theoretical and practical perspective on well-being and psychosocial adjustment. Journal of Counselling Psychology 51: 482509.

42. Hiroeh U, Appleby L, Mortensen PB, Dunn G (2001) Death by homicide, suicide, and other unnatural causes in people with mental illness: A population-based study. Lancet 358: 2110- 2112.

43. Liu Q, Shono M, Kitamura T (2009) Psychological wellbeing, depression, and anxiety in Japanese university students. Depression \& Anxiety 26: 99-105.

44. Salami SO (2011) Personality and Psychological Wellbeing of Adolescents: The Moderating Role of Emotional Intelligence. Social Behaviour and Personality: An International Journal 39: 789-794.

45. Diener Ed (1984) Subjective Well-Being. Psychological Bulletin 95: 34.

46. Ryan R, Deci E (2001) Self-determination theory and the facilitation of intrinsic motivation, social development, and well-being. American Psychologist 55: 68-78.

47. Abbott RA, Ploubidis GB, Huppert FA, Kuh D, Wandsworth MEJ, et al. (2006) Psychometric evaluation and predictive validity of Ryff's psychological well-being items in a UK birth cohort sample of women. Health Quality of Life Outcomes 4: 1-16.

48. Conway C, MacLeod A (2002) Well-being: Its importance in clinical research and practice. British Journal of Clinical Psychology 16: 26-29.

49. Wood AM, Joseph S (2009) The absence of positive psychological (eudemonic) well-being as a risk factor for depression: A ten-year cohort study. Journal of Affective Disorders 122: 213-217.

50. Ruini C, Fava GA (2009) Well-being therapy for generalized anxiety disorder. Journal of Clinical Psychology: In Session 65: 510-519.

51. Malek MDA, Mearns K, Flin R (1994) Stress and psychological well-being in UK and Malaysian fire fighters. Cross Cultural Management: An International Journal 17: 50-61.

52. Giltay EJ, Kamphuis M, Kalmijn S, Zitman FG, Kromhout D (2006) Dispositional optimism and the risk of cardiovascular death: the Zutphen Elderly Study. Archives of Internal Medicine 166: 431-436.
53. Greenleaf C, Boyer E, Petrie T (2009) High school sport participation and subsequent psychological well-being and physical activity: the mediating influences of body Image, physical competence, and instrumentality. Sex roles 61: 714-726.

54. Baruth M, Lee DC, Sui X, Church T, Marcus B, et al. (2011) Emotional Outlook on Life Predicts Increases in Physical Activity Among Initially Inactive Men. Health education and Behaviour 38: 150-158.

55. Fredrickson B, Mancuso R, Branigan C, Tugade M (2000) The Undoing Effect of Positive Emotions. Motivation and emotion 24: 237-258.

56. Azizi Y, Jaafar SL (2005) Development of Self Concept. Pahang: PTS publishing.

57. Smolak L (2004) Body image in children and adolescents: where do we go from here? Body Image 1: 15-28.

58. Bean L, Lipka R (1984) Self-concept, self-esteem and the curriculum. Boston, MA: Allyn and Bacon.

59. King A, Kiernan M, Ahn D, Wilcox S (1998) The effects of marital transitions on changes in physical activity: results from a 10-year community study. Annals of Behavioral Medicine 20: 64-69.

60. Strage, A. \& Brandt, T. S. (1999). Authoritative parenting and college student's academic adjustment and success. Journal of Educational Psychology 9: 146-156.

61. Ochse C (2003) Are positive self-perceptions and optimistic expectations really beneficial in an academic context? South African Journal of Higher Education 17: 567-573.

62. Lifespan (2006) Negative Body Image Related To Depression, Anxiety And Suicidality. Science Daily.

63. Dorian L, Garfinkel P (2002) Culture and body image in western culture. Eating and Weight Disorders 7: 1-19.

64. Lin L, Kulik J (2002) Social comparison and women`s body satisfaction. Basic and Applied Social Psychology 24: 115-123.

65. Furnham A, Borovoy A, Henley S (1986) Type A behaviour pattern, the recall of positive personality information and self-evaluations. British Journal of Medical Psychology 59: 369-374.

66. Levy BR, Slade MD, Kunkel SR, Kasl SV (2002) Longevity Increased by Positive Self Perceptions of Aging. Journal of Personality and Social Cognition 83: 261-270.

67. Fox KR (2000) Physical activity and mental health promotion: the natural partnership. International Journal of Mental Health Promotion 2: 4-12.

68. Franzoi SL, Shields SA (1984) The body esteem scale: Multidimensional structure and sex differences in a college population. Journal of Personality Assessment 48: 173-178.

69. Hausenblas HA, Fallon EA (2002) Relationship among body image, exercise behavior, and exercise dependence symptoms. International Journal of Eating Disorders 32: 179-185.

70. Cash TF, Pruzinsky T (1990) Body Image: Development, deviance, and change. New York: Guilford Press.

71. Lawlor DA, Hopker SW (2001) The effectiveness of exercise as an intervention in the management of 
depression: Systematic review and meta-regression analysis of randomised controlled trials. British Medical Journal 322: 763-767.

72. Stephens, T. (1988) Physical Activity and Mental Health in the United States and Canada: Evidence from Four Population Surveys. Preventive Medicine 17: 35-47.

73. Biddle JH, Mutrie N (2001) Psychology of physical activity: Determinants, well-being and interventions. London: Routledge.

74. Stewart R, Richards M, Brayne C, Mann A (2001) Vascular risk and cognitive impairment in an older, British, AfricanCaribbean population. Journal of the American Geriatrics Society 49: 263-269.

75. Goodwin C (2003) The semiotic body in its environment

76. Abu-Omar K, Rütten A, Robine JM (2004) Self-rated health and physical activity in the European Union. Sozialund Präventivmedizin 49: 235-242.

77. Bartholomew J, Morrison D, Ciccolo J (2006) Effects of Acute Exercise on Mood and Well-Being in Patients with Major Depressive Disorder. Medicine and science in sports and exercise 37: 2032-2037.

78. Armstrong S, Early J (2009) Social Connectedness, Self-Esteem, and Depression Symptomatology among Collegiate Athletes versus Nonathletes. Journal of American college health: J of ACH 57: 521-526.

79. Rejeski WJ, Brawley LR, Shumaker SA (1996) Physical activity and health-related quality of life. Exerc Sport Sci Rev 24: 71-108.

80. Derman W, Schwellnus MP, Lambert MI, Emms M, Sinclair-Scott C, et al. (1997) The 'worn-out athlete': A clinical approach to chronic fatigue in athletes. Journal of Sports Sciences 15: 341-351.

81. Zahran HS, Zack MM, Vernon-Smiley ME, Hertz MF (2007) Health related quality of life and behaviours risky to health among adults aged 18-24 years in secondary or higher education: United States, 2003-2005. Journal of Adolescent Health 41: 389-397.

82. Sundblad GB, Jansson A, Saartok T, Renstrom P, Engstrom LM (2008) Self-rated pain and perceived health in relation to stress and physical activity among school students: a 3-year follow up. Pain 136: 239-249.

83. Coleman, Hendry L, Kloep M (2007) Understanding Adolescent Health.

84. Baker K, Coleman J, Hendry LB, Kloep M (2007) Adolescence and health. John Wiley \& Sons: Chichester, UK 2007: 256.

85. Hausenblas HA, Mack DE (1999) Social physique anxiety and eating disorder correlates among female athletic and nonathletic populations. Journal of Sport Behavior 22: 502-513.

86. Van de Vliet P, Van Coppenolle H, Knapen J (1999) Physical measures, perceived physical ability, and body acceptance of adult psychiatric patients. Adapted Physical Activity Quarterly 16: 113-125.

87. Bahram A, M Shafizadeh (2006) A comparative and correlational study of the body-image in active and inactive adults and with body composition and somatotype. J Applied Sci 6: 2456-2460.
88. Fisher L, Berkey C, Colditz G (2007) Adolescent physical activity and perceived competence: Does change in activity level impact self-perception? Journal of Adolescence Health 40:1-8.

89. Brausch AM, Muehlenkamp JJ (2007) Body image and suicidal ideation in adolescents. Body Image 4: 207-212.

90. Kirkcaldy B, Shephard R, Siefen G (2002) The relationship between physical activity and self-image and problem behavior among adolescents. Social psychiatry and psychiatric epidemiology 37: 544-550.

91. Serdula MK, Williamson DF, Anda RF, Levy A, Heaton A, et al. (1994) Weight control practices in adults: results of a multistate telephone survey. American journal of public health 84: 1821-1824.

92. Biddle SJH, Fox K, Boutcher S (2000) Physical Activity Psychological well-being. London: Routledge.

93. Harter S (1985) Manual for the self-perception profile for children. Denver, CO: University of Denver Press.

94. Walcott-McQuigg JA, Sullivan J, Dan A, Logan B (1995) Psychosocial factors influencing weight control behavior of African American women. Western Journal of Nursing Research 17: 502-520.

95. Fava GA (1999) Well-being therapy: conceptual and technical issues. Psychotherapy and Psychosomatics 68: 171-179.

96. Seligman MEP, Steen TA, Park N, Peterson C (2005) Positive psychology progress: Empirical validation of interventions. American Psychologist 60: 410-421.

97. Petruzzello SJ, Landers DM, Hatfield BO, Kubitz KA, Salazar W (1991) A metaanalysis on the anxiety-reducing effects of acute and chronic exercise. Sports Medicine 11: 143-182.

98. Wang C, Bannuru R, Ramel J, Kupelnick B, Scott T, Schmid CH (2010) Tai Chi on psychological wellbeing: systematic review and meta-analysis. BMC Complementary and Alternative Medicine 10: 23.

99. Leith L (1994) Foundations of exercise and mental health. Western Virginia: Fitness Information Technology link, Inc.

100.Ekkekakis P (2003) Pleasure and Displeasure from the body: Perspective from exercise. Cognition \& Emotion 17: 213-239.

101.Hones M, O’Beney C (2004) Promoting mental health through physical activity: examples from practice. Journal of Public Mental Health 3: 39-47.

102. Hawkins MS, Storti KL, Richardson CR, King WC, Strath SJ, et al. (2009) Objectively measured PA of USA adults by sex, age, and racial/ethnic groups: a cross-sectional study. International Journal of Behavioural Nutrition and Physical Activity 6: 31.

103. Virkkunen H, Kauppinen T, Tenkanen L (2005) Long-term effect of occupational noise on the risk of coronary heart disease. Scandinavian Journal of Work, Environment and Health 31: 291-299.

104. Brownson R, Eyler A, King A, Brown D, Shyu YL, et al. (2000) Patterns and Correlates of Physical Activity among US Women 40 Years and Older. American Journal of Public Health 90: 264-270. 
105. Theodoratou M, Dritsas I, Saltou M, Dimas V, Spyropoulos A, et al. (2016) Physical exercise and students' mental health. European Psychiatry 33: S219.

106.Bauman A, Sallis J, Dzewaltowski D, Owen N (2002) Toward a better understanding of the influences on Physical Activity: The role of determinants, correlates, causal variables, mediators, moderators, and confounders. American Journal of Preventive Medicine 23: 5-14.

107.Chung PK (2003) Physical self-concept between PE major students and non-PE major students in Hong Kong students. Journal of Exercise Science and fitness 1: 41-46.

108. Brown W, Young A, Byles J (1999) Tyranny of distance? The health of mid-age women living in five geographical areas of Australia. The Australian Journal of Rural Health 7: $148-154$.

109. Gordon-Larsen P, Nelson M, Page P, Popkin BM (2006) Inequality in the Built Environment Underlies Key Health Disparities in PA and Obesity. Pediatrics 117: 417-424.

110. Van Domelen DR, Koster A, Caserotti P, Brychta RJ, Chen KY, et al. (2011) Employment and physical activity in the U.S. American Journal of Preventive Medicine 41: 136-145. 